\section{Radiation doses}

SIR - The National Radiological Protection Board may well have been courageous in projecting 13 fatal cases of thyroid cancer from the Windscale accident (Nature 17 March, p.207) but the accuracy of this result is subject to serious doubt. By relying on the concept of the man-sievert, the need to "look up the dose-response relationship" is eliminated although a straight line is implied which denotes proportionality between dose and incidence. The admission that even in such a large population the radiogenic cancers are not detectable, together with the absence of accepted scientific justification for the "linear hypothesis" of radiation carcinogenesis (especially when extrapolated to minute doses) weakens this exercise more than the other limitations mentioned in your report.

Until radiobiology advances well beyond its current capabilities we won't know what it was that we did not detect.

HARALD H. ROSSI

College of Physicians and Surgeons

of Columbia University,

New York, USA

SIR - I was surprised to read in your issue of 17 March (p.207), "Resurrecting a nuclear accident", that you find the unit man-sievert "chauvinistic". Units cannot all be named after British scientists. I am sure you would not condone an insult to the Swedish nation, so perhaps it is the apparent maleness that your reviewer cannot stomach. Would (s)he rewrite the poets: the child is parent to the person? The $\mathrm{Na}$ tional Bitch and Dog Owners Association will be the required title before we know where we are and the Horse-and-MareRace Betting Levy Board.

London W11, UK

D.K. BEWLEY

\section{Koestlers' choices}

SIR - In your leading article "The worm in the bud" (Nature 10 March, p.93) you equate suicide with the assertion of personal freedom. You go on to suggest that through his suicide, Arthur Koestler was directly responsible for his wife's premature death. These premises lead you to conclude that he should not have committed suicide. In my opinion, your judgment fails to address the essential issues in the case.

First, in saying that Arthur Koestler exercised his personal freedom by ending his life, you assume that Cynthia Koestler would have preferred her husband to live on. The short time that Arthur Koestler had left to live would have brought his wife the agony of seeing his increasing debilitation by disease. She may have agreed with him on the desirability of his suicide.

Second, we cannot assume that Cynthia Koestler's suicide was, as you claim, a "consequence" of Arthur Koestler's suicide. According to all reports, she had an extraordinarily strong attachment to her husband. She might have chosen to commit suicide even had he died naturally.

Finally, no one but Cynthia Koestler herself could decide whether to end her life. To assign to Koestler responsibility for his wife's decision to die with him diminishes her dignity as a human being.

No one can know the reasons for any suicide. If we must make moral judgment at all, we can at least try to appreciate the complexities of each case. Instead, your article simply reaffirms accepted attitudes of disapproval towards suicide. As an epitaph to Koestler your article could hardly do better than to project the conventional viewpoint. It seems fitting that he should die as he had lived: at the leading edge of evolving social values. M.R. VAN SCHRAVENDIJK Bethesda, Maryland, USA

SIR - I deplore your editorial remarks on the suicide of Mr and Mrs Koestler (Nature $10 \mathrm{March}, \mathrm{p.93}$ ). If matter and energy are interchangeable then death has no meaning other than a change of focus or of phase. Any sense of deprivation we feel is purely selfish. In my view, and those of other members of EXIT (now the Voluntary Euthanasia Society) Mr Koestler and his wife are at liberty to decide when and how they move out of the world in which we can see them: that is "life". Society, and those remaining, are neither "enhanced" (as you put it) nor degraded by their action.

\section{London N16, UK}

ANITA AIROLDI

\section{First use of biologie}

SIR - A modern American textbook ${ }^{1}$ on the history of biology (or life sciences) says "The term 'biology' was first introduced at the very beginning of the nineteenth century and publicized by the writings of the French zoologist, Jean Baptiste Lamarck (1744-1829), and a German naturalist, Gottfried Treviranus (1776-1837)." In fact Gottfried Reinhold Treviranus used the word in his Biologie oder Philosophie der lebenden Natur für Naturforscher und Ärzte (six volumes, Gottingen 1802-1822)

Lamarck first used the term biologie in his work Hydrogéologie, ou recherches sur l'influence qu'ont les eaux sur la surface du globe terrestre, published in Paris in December 1801 or January $1802^{3,4}$. Lamarck in his book divides the "physics of the Earth into three essential parts, the first being a theory of the atmosphere, or Meteorology, the second, a theory of Earth's crust or hydrogeology, and the third, a theory of living organisms, or biology"4. The planned book on biologie never appeared but was replaced by Lamarck's famous Philosophie zoologique (1809). However, a manuscript by Lamarck survives with the title: "Biologie/ou/Considérations sur la nature, les facultés, les développemens et l'origine des Corps vivans's. This is thought to be a draft of a work on written between 1800 and 1801 . In fact the word biologie was in use in 1800 , before Treviranus and Lamarck. Karl Friedrich Burdach (1776-1847), anatomist and physiologist in Dorpat (today Tartu) and Konigsberg, coined the word in his treatise: Propädeutik zum Studium der gesammten Heilkunst. Ein Leitfaden akademischer Vorlesungen', Leipzig $1800^{6}$.

But the very first time the word biologie appears in printed form is in the year 1797. In the Vorrede to his book: Grundzulge von der Lehre von der Lebenskraft, (Braunschweig 1797) Theodor Georg August Roose (1771-1803) referred to biologie ${ }^{7}$. Roose used the word only in the Vorrede and it does not reappear in the main text. This first edition of Roose's book was subject to a critical review, anonymously published in 1801 in Neue allgemeine deutsche Bibliothek, and the reviewer stated that Roose wanted to call "biology" what otherwise was named "physiology". So apart from Roose himself we have, in 1801, shortly after Burdach and slightly before Treviranus and Lamarck, another printed version of the word biologie.

Who was Th. G. A. Roose? Unfortunately, biographical material about Roose is scarce, but we know that he was a professor of anatomy in his native town of Braunschweig, and that he was awarded the title of Hofrat after not accepting a call to the university of Kiel in 1802. Apart from his own medical writings he was occupied with translating works by others such as those of Anton Scarpa from Pavia, Italy. He died, comparatively young, of a nervous fever.

Lehrstuhl für Biogeographie,

Universitat des Saarlandes, Saarbrücken, FRG

1. Magner, L.N. A History of the Life Sciences (New York, 1979).

2. Hoppe, B. Colloque International "Lamarck", 199-273 (1971).

3. Morgue, R. J. comp. Neurol. 56, 503-510 (1932).

4. Siafleu, F.A. Texon 20, 397-442 (1971).

5. Klein, M. Archs Anat. histol. embryol. 37, 105-114 (1954).

6. Schmid, G. Nova Acta Leopoldina N.F. 2, 597-620 (1935).

Dittrich, M. Comm. Hist. Artis Med. 83-74, 73-85 (1974)

\section{Course geography}

SIR - May I correct a geographical error in your article on Floyd Bloom's move from the Salk Institute to Scripps Clinic (Nature 3 March, p.3). As I remember the California coast at this point, Scripps overlooks the tenth fairway of Torrey Pines south course, and Salk runs alongside the 13th. Although my sense of direction (like that of my golf shots) is not outstanding, I figure this means that Bloom will in fact be moving northwards (away from Mexico), and not southwards as stated.

University of Leicester,

P.H. Williams

Leicester, UK 